\title{
Digital Inclusion for Indigenous People: Techniques for using computers and smartphones among the Pataxó of Aldeia Velha (Bahia, Brazil)
}

Isaac Fernando Ferreira Filho'

1 Universidade Federal da Paraíba, Laboratório de Estudos em Processos Técnicos, João Pessoa/PB, Brasil

\begin{abstract}
This article reflects on information and communication technology from the perspective of the Anthropology of Technique. It provides an ethnography of technical relationships and interactions that occur through the medium of computers, smartphones and software, among the Pataxó of Aldeia Velha, in the far south of the Brazilian state of Bahia. These relations both transform and are transformed by the social morphology of the group, generating new skills, mobilizing and organizing material flows and revealing new operational sequences.
\end{abstract}

Keywords: pataxó, technique, technology, smartphones, social morphology. 


\section{Inclusão digital entre povos indígenas: técnicas de uso de computadores e smartphones entre os Pataxó da Aldeia Velha (Bahia, Brasil)}

\section{Resumo}

Através de investimentos etnográficos, este trabalho busca fazer uma reflexão sobre tecnologias da informação e comunicação sob uma ótica da Antropologia da Técnica. Os casos apresentados ilustram as relações e interações técnicas que ocorrem na Terra Indígena Pataxó Aldeia Velha, no extremo sul da Bahia - Brasil, com usos de computadores, smartphones e softwares. Tais relações e interações transformam e são transformadas pela morfologia social do grupo, gerando novas habilidades, mobilizando e organizando fluxos de materiais e promovendo cadeias operatórias inéditas.

Palavras-chave: pataxó, técnica, tecnologia, smartphones, morfologia social. 


\section{Digital Inclusion for Indigenous People: Techniques for using computers and smartphones among the Pataxó of Aldeia Velha (Bahia, Brazil)}

Isaac Fernando Ferreira Filho

\section{Introduction}

This article reflects on the use of computers and smartphones by the Pataxó of Aldeia Velha (literally, 'Old Village'), an Indigenous Land situated at the far south of the Brazilian state of Bahia, in the North-eastern region of Brazil. Through the description of ethnographic cases, I intend to provide new discussions and analytical possibilities to the broad field of the study of technical relations. As a starting point, I will consider processes of transferring technology and their developments, focusing not on the question of its eventual successes or failures, but rather on how new techniques are incorporated, meanings are re-elaborated and individuals are engaged.

In the first section I present a panorama of the problems broached in the article. I also describe the concepts of 'technique', 'technology', 'transferences' and 'modalities of use' of technical objects, as discussed by numerous authors through varied analytical approaches.

In the next section, I describe the ethnographic context in which the analyses described previously will be investigated. I present how different Indigenous actors in Aldeia Velha organize to ensure access to resources and spaces where computers and smartphones can be used. I also describe the digital inclusion projects in progress among the Pataxó, which will illustrate the dynamic present in the transferences of technology, and provide greater detail on the daily relations of the inhabitants of Aldeia Velha.

The third section furnishes an ethnographic description of how the mass-dissemination of smartphones enabled certain changes in hierarchical and power relations among the Pataxó. I also describe here how technical choices concerning smartphone models and apps are arrived at. Simultaneously, I reflect on the skills and potentialities afforded by these new devices in what concerns the social organization and techniques of the Pataxó.

Finally, in the conclusion, I will show how the technical transformations described in the article imply a transformation in Indigenous social morphology.

\section{Technical Relations: Subjects, Artefacts and Environments}

It is undeniable that the paradigm of the so-called 'new technologies' has undergone a great transformation. The computer, as we know it, which had previously been at the heart of information and communication technologies, has been losing ground to smartphones, particularly in the market of end-users, an expression for individuals who use computers but do not work directly with technology. Mobile devices have gradually become more conspicuous. In Brazil, in what concerns internet access, mobile devices overtook personal computers in 2014 . 
Many academic disciplines have taken note of this change. In the human sciences, we have a range of studies, mostly in the area of cyberculture. Anthropology has also weighed in, with a number of studies having been organized by Daniel Miller, who is currently managing a project called "The Anthropology of Smartphones and Smart Ageing (UCL Anthropology, 2018)", with ten participating anthropologists carrying out research all over the globe.

This project follows another from 2016, in which Miller and eight other researchers released a book, resulting from 15 months of ethnographic fieldwork. The authors' reflections on social media offer important insights into the themes and approaches of this article. It is evident that, when writing of the use of devices such as computers and smartphones, we are also dealing with internet connection and with the vast field of social media. Miller et al (2016) clearly strive to overcome claims based on hasty generalizations concerning the use of these technologies, through studies of various groups in different countries and contexts.

What needs to be observed are the localized data that investigations can reveal, which requires a dynamic approach that takes into account differences in gender, age, power and formal education, rather than a unitary view of the development of the internet along a singular path (MILLER et al., 2016). Another pertinent critique by the authors concerns an over-simplification of matters of use in public and private spheres, as well as treatments of the impact of technology on people who tend to create two worlds, one online and another offline.

Miller et al's (2016) analysis seeks to question the phenomena of social media, to carefully bring out its complexity and accomplishing a vast comparative study that interrelates continents, countries, cities and groups. Their reflections are also pertinent to the present study, turning to the usages and possibilities that the devices enable, connecting the individual to social media. As we will see below, when it comes to smartphones, more doors are opened, with a broad participation of individuals in the worldwide web.

How does all of this play out in an Indigenous village? This is a fundamental question, which underscores this study. Bringing an Indigenous experience to this field of analysis takes us further from outdated narratives of an encounter between two worlds, with, on the one hand, the Indigenous people as avatars of the traditional, and, on the other, new technologies as symbols of what is most modern. Ethnic borders are aligned with and attributed according to modes of usage and the production of objects, so that, even if a people do not have the technical capacity to produce a certain product, this product is nonetheless often considered to belong to them (MURA, 2011).

Other relevant questions concern social morphology (MAUSS, 2015b), which, when observed and analysed at a deeper level, provides us with an important panorama of its transformations vis-à-vis certain phenomena. Villages display certain peculiar characteristics when compared to more usual contexts for research on the use of technology. It is evident that each context possesses its own dynamics, resulting from numerous social processes experienced throughout history. This is a crucial topic, since, according to Mauss, "the telluric factor should be related to the social medium in its complexity. It cannot be isolated” (MAUSS, 2015b, p. 427).

This being so, certain points emerge as relevant in my analysis. The way that families are organized may exercise greater moral pressure, since family members who live close to each other can constrain specific acts. Despite its proximity to the centre of the Arraial D'Ajuda district, Aldeia Velha is very different from the heterogeneity of an urban context.

Following Mauss (2015b), observing social morphology furthers our understanding of sociotechnical processes, since it transforms and is transformed by usage of objects and the incorporation of new techniques. This multiplicity is here understood as a combination of all the environments and matters related to the political ordering of the village, to religious condition, among other aspects present in that space that channels the various flows. This will become clearer when I contextualize the Aldeia Velha Indigenous Land and its practices. 
My investigation looks beyond the artefact itself, toward an understanding of the paths that lead to the diverse uses enabled by a vast field of technical concatenations. I question the line of thinking that focuses on the use of informational devices as something that is exterior, annexed to the individual, by hybridizing subject and object. We understand these uses to be a process of exteriorization which has been constantly evolving through the release of both body and memory. This idea is important, supplying us with elements for a different understanding, since it is still common to conceive of artefacts as something beyond the human, which creates the impression that the technologies in vogue today (smartphones, computers, artificial intelligence, etc.) are completely distant from the social world; or, as Simondon (2007) put it, technical objects are considered foreign even though they are human products.

This process of liberating mind and body has been seminally developed by Leroi-Gourhan (1987), who, in brief, describes it processually, narrating the human adventure through diverse movements. Beginning with freeing up quadruped mobility, culminating in freeing up the hands, which, in conjunction with acts of feeding, frees up the mouth, making verbalization possible. With each of these events of liberation, other elements are able to specialize even further, widening the operational sequences of the subject.

Concerning exteriorization, the author considers that human history displays an expansion of memory, which gradually becomes collective, transitioning between groups. In the process it comes to be decodified, written and stored in books, which, in due time, incorporate new techniques, such as catalogue cards and information that will later be indexed. These types of indexation of information enable the use of perforated cards, which are at the origin of electronic memory (Leroi-Gourhan, 1987). As early as 1966, the author had already predicted that:

What is already clear is that we know how to, or very soon will come to know how to, build machines capable of recalling everything, and to decide on the most complex matters without making mistakes. This simply reveals that the cerebral cortex, much like the hand or the eye, as admirable as it may be, is insufficient, and that methods of electronic analysis can overcome its deficiencies [...] (LEROI-GOURHAN, 1987, p. 67).

Despite the work of Simondon and Leroi-Gourhan being exceptionally relevant to contemporary studies, it should be emphasised that they were written during a time (the 1950s and 1960s) when computers were yet to become important to society. As we can see from the passage above, Leroi-Gourhan's thought looks ahead of his time, when computers were undergoing significant changes, passing through first, second and third generation models (UFPA 2015). Some important transitions include: the change from vale to transistor, which increased speed and decreased prices; the change from binary to symbolic language (from o's and 1's to something closer to standard English); and the introduction of keyboard and monitor as alternatives to perforated cards and printers, which were previously the only input and output devices.

It is thus useful to think of the devices studied here as exteriorizations of human beings, rather than the contrary. It is likewise useful to conceive of contemporary smartphones and computers as elements that enable an amplification of the technical skills of individuals, concatenated in their technical performances.

There are two further important concepts elaborated by Leroi-Gourhan, that of technical tendency and technical fact. For the author, these concepts are two sides of the same phenomenon. Technical tendency is predictable, inevitable and rectilinear, leading, for example, "a flint held in the hand to acquire a handle" (Leroi-Gourhan 1984, p. 24). Technical Fact, in turn, is unpredictable and specific, resulting from the encounter between the tendency "and the thousand coincidences in-between" (Leroi-Gourhan 1984, p. 24). According to the author, tendency, unlike fact, is an abstract concept involving the causal effects of man on matter, and moving beyond these types of acts. 
The concept of technical tendency allows us to understand how certain technical transformations can be triggered, favouring the development of specific technical experiences and concatenations in a given sociotechnical context. In what pertains to the present analysis, I will show, throughout the article, how during fieldwork I observed a technical transformation involving a tendency to replace computers with smartphones. This substitution is relative to a number of factors which take into account the conditions of availability of and accessibility to the materials desired by the Amerindians. Mura defines the balance between what is available and what is accessible as a "repertoire of possibilities":

The availability of materials and their accessibility in the territory have an influence on both the conditions of the territory and the decision-making possibilities of the social actor who can participate in different levels of this process. In this way, the interaction of the landscape - as ends, plans and expectations - with the binomial availability/accessibility will determine what I have called a repertoire of possibilities (MURA, 200o).

Considering activities and technical choices through a certain repertoire of possibilities allows us to conceive of the technical tendency in a wider sense, not only in relation to humans and matter, but including, within the technical process that allows us to apprehend it, political aspects and subjective and collective intentionalities. Mura (2017) draws attention to the need to consider political action itself as technical behaviour, since it is a fundamental component for understanding technical processes and ways of defining specific operational sequences in specific contexts.

Fieldwork among the Pataxó of Aldeia Velha indicated certain uses and possibilities, not only in what concerns smartphones, but for computers in general. In my early research, I reflected in the construction of technical relations resulting from the transferral of technologies, between projects of digital inclusion and the Pataxó, specifically focusing on projects that used free software. During my research, I observed diverse experiences, occurring in different spaces, that were conceived as catalysts for a more equitable access to information and communication technology, alongside significant change in the configuration of varied activities between the individuals and groups involved. It is this diversity that I will discuss in this article.

Before proceeding, I will expound certain points that will illuminate the claims made throughout the article, and also avoid discussions which were more adequately addressed in studies by important authors. To begin with, I would like to query the usual understanding of the concept of 'technology'.

Some anthropologists have provided important reviews of studies of technology and technique. In some translations into Portuguese, the concepts of 'technique' and 'technology' are at times mixed up, causing confusions. In an article called 'Science and Technique', Sautchuk argues that a preference for 'technique' over 'technology' is not tantamount to a rejection, but to caution. Usage of the concepts of 'technique' and 'technology' are linked to regional contexts: in Anglo-Saxon countries and in Brazil, the term 'technology' is more common, whereas in Francophone countries the term 'technique' is preferred. Indeed, in the translated works of certain French authors, 'technique' is rendered as 'technology' (SAUTCHUK, 2010).

I will here use the term 'technology', with the requisite caution, since it can take us along a path riddled with dichotomies such as traditional-modern, subject-object, and nature-culture. Within anthropology, these famous dichotomies have been superseded, both on a methodological plane and in a conceptual plane (INGOLD, 1988; MURA, 2011). Unlike other specializations, the anthropology of technique has been analytically engaging with humans, nonhumans, and technique beyond deterministic and/or utilitarian paradigms.

Following this argument, considering the theme of the article, which involves information and communication technologies, it is worth recalling issues raised by Bryan Pfaffenberger (1992) concerning a standard view of technology. He argues that there is a wonderment that stems from this view that takes technological knowledge as a pillar of Modernism, which contributes to what I raised above through the studies of Leroi-Gourhan (1987), Simondon (2007) and Miller et al. (2016). 
It should be stressed that this type of wonderment is not exclusive to the present, to our "technological world". The Italian philosopher Paolo Rossi, recovering a statement by Campanella, writes that there was "more history in one hundred years than the world had in four millennia" (CAMPANELLA, 1941 apud ROSSI, 1989, p. 64). They are referring here to $18^{\text {th }}$ Century, and the technological novelties that the authors refer to are the magnet and the press. Pierre Lévy (1993) also mentions this wonderment, in reference to the printing mutation that would lead to the printing of books. This artefact, with its evolution, would become mobile, easy to handle on a day-to-day basis, and also available for personal appropriation (LÉVY, 1993). We might easily bring this past wonderment, with the advent of the magnet, the press, the book, and apply them to the appearance of the smartphone, which today occupies the peak of our fascinations.

Against this view, we here take the concept of technology as a process of design - that is, as planned in the mind of an individual and introduced into a system (INGOLD, 1988). This way, as I will show throughout the article, assuming this standard view renders invisible the sociotechnical system (PFAFFENBERGER, 1992), separating it into two processes: thinking and doing. The latter, according to Ingold (1988), gradually becomes "merely technical" and it is, consequently, lessened. This separation contributes to a radical divide between what is technical, what is social, and what is political.

We have an outstanding contribution to the study of technique in Mauss, who helped elevate technique to a major topic. For Mauss, the study of technique is central not only to understanding objects or machines, but also social morphology, space and time, gestures, movements and knowledge itself (MAUSS, 2015a). In what pertains to the transferral of technology, a technical analysis reveals a greater complexity than one focusing on the adequacy of the use of a technological package.

Success and failure of products go beyond a simple relation between producer, consumer and middlemen. A smartphone device purchased in Brazil may have been projected in the USA, using raw material mined elsewhere, such as in Africa, assembled in China, arriving in Brazil through various means. Perhaps a company secured a deal with a Brazilian company, or received some sort of tax break, or maybe it was brought here by small-time businessmen who bought them abroad to sell them here.

During this trajectory, political and social elements are completely inherent and active within a sociotechnical web, and they cannot be analytically separated. What falls to the analyst is to reveal these relations, which may, at first, seem concealed.

Concerning technical acquisitions among ethnic groups, their successes and failures, Leroi-Gourhan (1984) argues that there may be three stages to a technical rejection: technical inferiority, where the group does not master essential associations; technical inertia, where there is no effort to assimilate a given technique; and, finally, the stage of technical plenitude, where the group has no interest in what is being offered.

Leroi-Gourhan (1984) elaborates hierarchies for these stages: very rustic; rustic; semi-rustic; semiindustrial; industrial. He later updated the hierarchy, changing it to: pre-artisanal; proto-artisanal; isolated artisanal; grouped artisanal; and industrial (LEROI-GOURHAN, 1984, p.33). The change was necessary because, according to the author, the initial hierarchy did not directly engage technology, as the term "rustic" had a more aesthetic meaning.

Despite this hierarchy, Leroi-Gourhan is clear that these relations can co-exist within one group. An ethnic group can thus have different experiences, and different ethnic groups can have the same experience. However, the author's analysis nonetheless focuses on production, disregarding issues of use and acquisition (MURA, 2011).

Considering these other relations, we can provide a wider reflection on the matter of the different ways that technology can be transferred. In the case at hand, it occurs through a process of inclusion, focused on access o use of the computer. Taking the use and dissemination of free software as an important factor, I will show how the understanding of philosophical political and technical elements were not assimilated as expected. 
The French engineer and sociologist Madeleine Akrich (1992) developed an interesting study of the matter. She argues that this expectation is typical of a designer who seeks to transfer a technical set to an imagined user. There is hence a script that should be followed for the transferral to be successful. What Akrich observed is that this expectation often finds a different user from that imagined by the designer. In this conflict between real user and imagined user (Akrich 1992), the approach moves through paths that diverge from a simple adoption. It must be considered that the adoption of a specific artefact does not imply in the adoption of the logic of the group that produced it.

Transferrals undergo numerous re-elaborations which culminate in functions and meanings that differ from their initial script. Through ethnographic engagement, we see that there are no neat frontiers between the hierarchies noted by Leroi-Gourhan (1984), and that, many times, they are jumbled up. Transferrals are thus concatenated in traditions of knowledge (Barth 2000), in a large flux of cultural and physical materials. To these are added social, political and symbolic principles (Mura 2011). That is, what is being transferred finds a body of technical knowledge that was constructed through processes that are not only social, but also environmental (Mauss 2015b), composing traditional local knowledges (INGOLD; KURTTILA, 2000).

With these conceptual and methodological precautions, this article concerns how technical skills are developed by the individuals of Aldeia Velha, and how these skills, as well as the technical objects associated with them, are concatenated in their operational sequences (LEROI-GOURHAN, 1987; CRESWELL, 1994; SIGAUT, 1994).

\section{Digital Inclusion in the Aldeia Velha Indigenous Land: Technological Transferrals, Experiences and Skill Generation}

Before presenting my thoughts on the sociotechnical relation in the field, I will provide a brief context of the field, to help the reader understand the approach I have adopted.

According to Mura (2006), within a western frame of thought the term 'village' designates nucleated spaces with bureaucratic forms of administration and political representation. Despite their similarities, each village has its own specific socio-historical processes, particularly when we consider a country of the territorial dimensions of Brazil, with political-regional divisions that result in an asymmetry of analyses. When we choose a village in the Northeast of Brazil this becomes especially evident. When compared to the Indigenous people of the Amazon region, Oliveria writes that:

Given the characteristics of the frontiers and their chronology of expansion in Amazonia, Indigenous people retain a significant part of their territory and ecological niches, while in the Northeast such areas were incorporated into earlier colonizing flows, their current lands not differing much from the peasant pattern, being interspersed with the regional population (OLIVEIRA, 1998, p. 53).

The Pataxó are among this latter lot, with the aggravating factor that their lands are on the stage of the Portuguese colonization of Brazil. According to Grünewald (2002) this contact was shot through with slave raids, deterritorialization and serious conflicts between Amerindians and colonizers ${ }^{1}$. There are currently twelve Pataxó Indigenous Lands², nine of which are in the state of Bahia and 3 in Minas Gerais.

\footnotetext{
1 Numerous ethnicities, among which the Pataxó, were gathered in colonial villages where they were completely forgotten. Their existence was unknown for some time, and it was even considered that the Pataxó were "extinct". For more details of this process, see: Carvalho (1977) and Grünewald (2002).

2 In the state of Bahia we have the following Indigenous Lands: Águas Belas, Aldeia Velha, Barra Velha, Comexatibá, Coroa Vermelha, Coroa Vermelha - Gleba C, Fazenda Bahiana, Imbiriba, Mata Medonha. In Minas Gerais: Cinta Vermelha Jundiba, Fazenda Guarani, Muã Mimatxi (Fazenda Modelo Diniz). According to FUNAI's records, these lands are in different stages of demarcation (under study, regularized, Indigenous reservation, delimited and declared). For a complete map and further information, see: http://www.funai.gov.br/index.php/indios-no-brasil/terras-indigenas. Accessed in August 2018.
} 
The Aldeia Velha Pataxó Indigenous Land is situated in the district of Arraial D’Ajuda (far south of Bahia, Brazil), some $2 \mathrm{Km}$ from its centre. Its total land is 2000 hectares and roughly 928 individuals live within its bounds (FUNAI, 2018). Along with residential houses, the land has a schoolhouse, a "culture point", a health post and three churches, one Catholic and two Protestant.

It is important to note the expressive Protestant contingent in Aldeia Velha. The fact is interesting because, as I will show later, certain religious positions contribute to the control over and flow of materials.

Political organization is centred on the figure of the cacique, elected by the inhabitants, and supported by other Indigenous leaders. As Pataxó villages are geographically close to one another, there is a significant flow between the inhabitants of different Indigenous Lands. It is common for "relatives" to visit each other, as is political articulations between Indigenous leaders.

When it comes to digital inclusion policies, we must keep in mind the developmentalist slant that is at its core. It carries with it categories such as developed, underdeveloped, First World, Third World (RIBEIRO, 2008), that imply an evolutionist trajectory in which a certain group must reach the technical-scientific-economic model of another group, the latter being seen as the "successful" one. It is thus seen to be necessary that this process be helped along, through interventions such as funding, investments, projects, and programmes for transferring technologies (FERREIRA FILHO, 2017b).

It is important to highlight certain aspects of the modalities of transferring technology. According to Cresswel (1983), there are problems with planning and policies that tend to ignore the social contexts in which these take place, or which focus primarily on the objects themselves, and not on the technical processes. This problem is also raised by Akrich (1992). The author stresses that transferrals of technology do not move toward an acritical recipient, nor will the characteristics of the transferred technology remain the same in the new context. Local social relations will thus play a significant role, which leads Cresswel (1983) to highlight the need to include the idea of an open system within these processes, in which non-linear pathways can be followed.

Another point that must be taken into account in transferrals of technology is their frequently homogenising character. They do not taking into account the local characteristics and the interests of the actors who are supposed to be the beneficiaries of these activities. These do not often perceive, or else fail to consider, that various technical objects have their functions re-elaborated according to local traditions of knowledge.

In what follows, I will focus, precisely, on the ideological and practical aspects of some processes of transferral of technologies that took place in Aldeia Velha.

During its history, Aldeia Velha underwent various projects of digital inclusion, stemming from a number of different initiatives. These were managed by different institutions, including government, NGO's, and other initiatives. I draw attention to two of these experiences. The first is the National Programme of Technological Education (Programa Nacional de Tecnologia Educacional, ProInfo), implemented in the school in 2009. This project was made possible by the Porto Seguro Secretary of Education (Bahia, Brazil), tied to a national policy of digital inclusion.

The second, Bailux, was experienced the following year. It began operating outside of Aldeia Velha, where Indigenous people went to a place with computers, internet and maintenance workshops, which made use of various software. After a while, this experience moved into Aldeia Velha, operating inside the school and later in an annex.

\footnotetext{
3 Arraial D'Ajuda is a district of the municipality of Porto Seguro which, along with the districts of Trancoso and Caraíva, are part of a tourism circuit of beaches.

4 The programme, according to the Amerindians, did not work satisfactorily, for it was far too bureaucratic for the reality of Aldeia Velha. For further details on its implementation and operation, see Ferreira Filho (2017b).
} 
Unlike ProInfo, Bailux was the brainchild of an individual who was a member of a collective of activists for "a critical appropriation of technology" called The MetaRecycling Network (Rede MetaReciclagem)5. It sought a different approach to government efforts at digital inclusion, even coming to reject the idea of "digital inclusion" altogether (FERREIRA FILHO, 2017a). The MetaRecycling Network always looked to work with distinct audiences, using other practices and spaces, such as the "culture points". Bailux thus followed a different logic when working with the Pataxó, starting from the a priori premise that the group would use technology in its own terms, tied to the appropriation of tools and meanings for emancipation and ideological activism.

Thus, while the ProInfo lab was a venue for digital inclusion aiming to transfer technology, supported by a discourse of democratic access to new technologies and targeting the Pataxó as an excluded target group, Bailux sought to promote a critical venue where communication and information technology would undergo appropriation, guided by the image of a population of Indigenous activists, thinking beyond a simple inclusive access and using technology as part of activist policies.

Despite their differences, both projects opted to use free software. Free software is the source of an intense debate because it champions a different business model from that of the computing market. Its proponents argue that software should be freely available to users. This is tied up with a different view of the ideological components of the process of software development, which has been investigated by a number of anthropologists (MURILLO, 2009; MILLER, 2015). The examples mentioned here themselves reveal the varied understandings of these software.

ProInfo was based on public policies and investments inherited by the Workers' Party (PT), which promoted its use as part of their policies of digital inclusion. Free software reduced costs with licenses, and, in consonance with the discourse surrounding it, was generally used as a means to resist the neoliberal policies of a globalized world. Bailux is also a product of this period of widening access to technologies, and of furthering free software as a means to achieve this end. Despite this conformity, the second project always took into account the possible specificities of Indigenous users. In this way, the use of computers concatenated various meanings that connected with the image of an Indigenous population in need. It is through this image that the computer and free software could become tools not only for counter-hegemonic engagement, but also for recovering cultural traditions.

My early research was concerned with how the computer was to be used in diverse contexts: how its tools (particularly software) were to be used for solving daily problems and generating income, and how free software was linked to political-ideological-moral matters, as well as with issue of familiarity with specific software. During my fieldwork, I learned that the use of free software was mostly unsatisfactory, at least from the point of view of those who brought it to the village.

It was clear that the Pataxó did not understand the specific meanings implied in the use of free software; others knew what it was, and even agreed with the issue raised by its use, but nonetheless felt that it did not solve daily problems in the village, since it was far too difficult to use, demanding further training.

The main operational system for free software is GNU/Linux, which, unlike Microsoft Word, requires the support of specialized technicians in order to allow users to grasp its basic operations. Another problem often noted by the residents of Aldeia Velha is that, at the time, many of its tools (pre-installed programmes) were in English. Using GNU/Linux thus required greater effort, both in acquisition, since few people at the village had it installed, and internet access was necessary to download it, as well as with its daily use.

\footnotetext{
5 MetaRecycling is a decentralized and self-organized network of various activists. It is principled on a critical appropriation of information and communication technology. The network also promotes actions involving collaboration, "hacker attitude", and free software. For more information on the network, see: Atroch (2015) and for more on its relations and actions in Aldeia Velha, see: Ferreira Filho (2017b).
} 
As I mentioned at the start of this article, information and communication technology are undergoing a paradigm shift. At Aldeia Velha, access to computers was only available to the few. In terms of public access, there was the school and the culture point. ${ }^{6}$ The former offered limited access to a few computers. Privately, the use of computers was likewise scarce. Some of the Pataxó with home computers were studying for teaching degrees.

In what concerns the acquisition of computers, I would like to present examples that I was able to observe under diverse factors: economic, spatial and infrastructure; and family hierarchies. The district in which Aldeia Velha is situated is a tourist spot, and the cost of living is relatively high, which also raises the price of computers. In the district itself, there are only three places where computers are sold, and they only tend to be visited when the odd emergencies occur. The usual option, not only for computers but for electronic devices in general, is to travel to the city of Porto Seguro, or, for those with the necessary experience, to buy it through the internet.

Along with the matter of acquiring a computer, it is also necessary to have a designated space for using them, particularly where desktops are involved. A basic infrastructure is also needed, including adaptors, electrical sockets with different fits, a voltage stabilizer. To explain the following, I will refer to ethnographic cases $^{7}$ that also touch on the two preceding points, showing their interlinkages, allowing us to envisage the specificities of the acquisition process.

The need for a computer was met in two distinct cases. In both, I took different computers to Aldeia Velha. In the first I took a computer case to fill a local administrative need. The Cacique had asked me about the possibility of buying a computer in my city (Recife), which would be cheaper. All he needed was a computer case, since he had a monitor and a mouse, which had been donated by a family friend. When I asked people I know about cheap computers, a friend of mine donated a computer in an excellent state. I made sure it was in fine condition before taking it to Aldeia Velha.

If we take into account the terms in which the discussion has been framed, we can say that the stage of acquiring a computer had been completed. However, there was still the need to acquire space and infrastructure, since it was a desktop computer. It was also necessary to take care and not connect it directly to a power outlet, which meant acquiring a voltage stabilizer. After remaining for some time inside the box, the computer was finally assembled when a stabilizer was obtained from the culture point.

Although the computer was not meant for personal home use, since it was installed in another space near the school, it was evident that the device required more physical space and electrical infrastructure. When it was set up for tests, it was placed in the kitchen, each of its parts in an improvised place. The voltage stabilizer was set beside a water fountain near a socket. The case on a stool and the monitor, keyboard and mouse were on the top of a table. Since the power cords and the sockets did not match, a connection had to be improvised using a piece of cut wiring, the "Type B" stabilizer plug and the "Type N" new Brazilian socket. This adaptation was used only for testing the computer; an adaptor was later acquired.

The second case involved taking another computer to a young man with great interest and skill in computing. Although he wanted to learn more, a series of problems immediately presented themselves. The first was very limited access to a computer, since there were no more computing classes in the school. A further problem was that, even if he could get access in school (when a teacher let him use it, for example) or when he borrowed a computer from someone, he was still unable to try out new skills, such as installing a new programme or changing the computer's operational system.

\footnotetext{
6 There were only two notebooks in the culture point. These were used by the local staff, as well as by visitors. Although the school had a "computer kit", it did not have a well-structured lab. For more on these spaces and the information laboratories, see: Ferreira Filho (2017b).

$7 \quad$ For more detail on both cases, see: Ferreira Filho (2017b).
} 
As with the cacique's house, a desktop computer would take up too much space, and he would have no way of keeping it in his home. As a solution, I suggested the use of a computer called Raspberry $\mathrm{Pi}^{8}$, which is roughly the size of a credit card and could be easily connected to a TV. It would thus not pose any problems of physical space, nor raise any issues of outlet adaptability, since its energy needs could be met through a USB chord, which was quite ubiquitous in the village, as it is the same type used for smartphones.

My suggestion came with an offer to donate the computer. Despite his enthusiasm, however, the young man could not accept the donation because of family problems. He would not share his reasons with me. He just said that his family had restrictions on computer use. I later learned that these restrictions were religious.

If we compare both of these cases, we see that the use of a computer has certain prerequisites. For both, the problem of acquiring the computer was solved by a donation, and difficulties involving space for the computer were solved using different strategies. However, in the second case family restrictions prevented the acquisition and use of a computer. The hierarchical aspect of our analyses is evident. An interesting aspect of Aldeia Velha is that many of its families are Protestant, including the two families involved in the cases described above.

Although it is not a unified discourse, there are significant cases in which there are religious interferences in the use of information and communication technology. These interferences range from an association between the electronic chip and the Biblical image of the Beast to demands from the pastor that the faithful cease to use social networks, particularly WhatsApp, for a certain period of time.

We can see here that the computers, as technical objects used as essential tools in the democratic access to new technologies, or even in Indigenist activism, were not transferred to daily usage. The research also revealed that the occasional use of the computer was losing ground to the use of smartphones. Taking this data into account, I would now like to turn to a comparative panorama of the use of computers and smartphones in Aldeia Velha, focusing on important elements of their use and acquisition.

\section{Between Computers and smartphones: techniques, concatenations and re-elaborations}

As we can see thus far, using a computer in Pataxó villages presents certain difficulties of various orders, not just economic. Owning a computer reveals certain important points, especially when attached to local uses that reflect specialized work which accrues prestige in the eyes of others. What I call specialized work, in this article, is work that needs a computer in order to fulfil its tasks.

I have categorized uses according to characteristics that, although far from rigid and exclusive, help me illustrate the different ends of the same object within the local context. I believe that the information analysed here can also aid in reflections on the transferral of technology, particularly when conceived as digital inclusion. Above I mentioned a degree of homogenisation, where possible solutions are based on an a priori view of their necessities, I here want to turn to some of the specificities encountered during fieldwork.

Bureaucracy is the main use not only for the computer, but also for an adequate connection to the internet. 'Bureaucracy' is used here in the sense of a way of dealing with recurring problems which range from public tenure to the Indigenous school, through public notices providing funds for village projects. The cliché "knowledge is power" applies here, since the ownership of a computer provides speedy access to certain information, such as knowing who was approved in a selection process for the Indigenous school. In this case, access to the internet was needed to download an electronic file listing the approved candidates. As well as a regularly functioning internet for downloading a large file, a monitor was also desirable, since it was hard to read the information on a smartphone screen. For this task, the easy solution was to head to a lan house to obtain the information on approved candidates, so that the appropriate actions could be taken.

8 This computer was created for teaching computer science during primary education. The hardware was conceived so as to be fully integrated, and to keep costs low. 
The need for other devices typically included with a computer can make certain tasks more efficient. A keyboard makes it easier to type up reports, notices, schoolwork, and to edit graphic and audio-visual material. Likewise, computers are useful for Indigenous teachers which, for the most part, are studying for teaching degrees. They use computers both as teachers and students, in researching for class, elaborating slide presentations, and producing texts for their courses. Those who do not own a personal computer, hope to acquire one, in order to have greater autonomy in these tasks, and to avoid borrowing from others.

A final use for the computer is for those who have jobs related to the maintenance of computing devices. I got know the main technician for this type of work in the village, which demands certain skills and the ownership of a number of devices (computers, components), but also software. If we were to make a hierarchy of these categories, this one requires the most skill in operating a computer, both in what concerns hardware and software. Since it requires a high degree of specialization, it is the rarest category to find in the area.

As I have mentioned, these categories are only meant to help illustrate a panorama that is certainly more complex. I also include here those few families that are aware that knowledge of how to use a computer may, in the future, prove an advantage in the job market, and therefore invest in information technology courses and the acquisition of computers for their children. The use and acquisition of computers is certainly directly linked to the social mobility of the individual. It is through these material flows that each individual must overcome economic and social factors, such as those mentioned above, concerning the young man who tried to convince his family to accept his use of a small computer given to him as a gift.

If, as we have thus far seen, the computer is an artefact that is hard to acquire, and which demands a certain specialization, as well as financial resources, to be able to use, it is now necessary to turn to smaller computer that has been present in the daily affairs, not only of the Pataxó of Aldeia Velha, but of all of us: the smartphone.

For lack of space, I am unable to provide a history of the smartphone, but will briefly recuperate a model which is commonly stressed today. It has been little more than a decade since the iPhone ${ }^{9}$ was released, and it was followed by a spate of phones that run on the Android operating system. Despite a small screen and the lack of a comfortable keyboard, it is widely used in the village. One of the descriptions given to me of the village is that, at night, there were "firefly Indians", that is, residents that used the led screens of their smartphones during their nocturnal strolls as torches to illuminate points within the Indigenous land that lacked electric lighting.

The choice of a smartphone over a computer can certainly be explained by economic reasons, but is this all there is? Which aspects reveal a preference for the smartphone? For there are other technical factors that guide these choices, and which vary between individuals. One starting point to think about these is the use of the internet.

Although the smartphone has advantages for internet access, since it can easily connect to a mobile network, the connection is not always the predominant factor in its acquisition. There are individuals who, despite owning a smartphone with internet access, have never used to access the internet. Why acquire it then? Its screen is larger than that of a feature phon $\mathrm{e}^{10}$, and therefore it has a larger keyboard for thick fingers to type in phone numbers. Logically, however, the ease of connection is a major selling point for other individuals, particularly for the use of messaging services such as WhatsApp. Since internet access is scarce in the region, smartphones prove to be adequate for two reasons. They can access mobile networks according to the plans and packages provided by the operators, and they allow people to connect to the wi-fi networks of neighbours and family members who have internet access.

\footnotetext{
9 Although the iPhone is considered to be an expensive smartphone for most of the population, it is nonetheless a fundamental aspect of the development of the Android. Despite the exclusive functions of each operating system, most functions are incorporated into both with each new version of the system or the creation of a new device. The development of one thus affects the development of the other.

10 Feature phones are those devices that possess limited resources, being used mainly for making phone calls and sending text messages (SMS - Short Message Service).
} 
I return now to the case of the young man whose family forbade him to have a computer. Under these circumstances, although access to a computer was restricted, he was allowed to use his smartphone freely. We can thus conclude that there is a wider tendency to accept this device, which is apprehended as a means to communicate with others (a phone) rather than as a "mini-computer".

If we return to the view of the computer as an artefact that is more constrained by hierarchy, which is available only for a select few, we can see smartphones as devices that converge the functions of a computer with features of the phone (figure 1). This new object reconfigures these positions, making access to digital resources more democratic, whether by reducing costs or by concatenating new techniques. Whereas with computers it is necessary to have labs with adequate infrastructure (network cables and electrical outlets), and individuals with an intimate knowledge of the operating systems in order to teach them to others, a variety of resources are at present gradually discovered through constant experimentation.

Figure 1: Comparsion between the functions of the feature phone and the computer

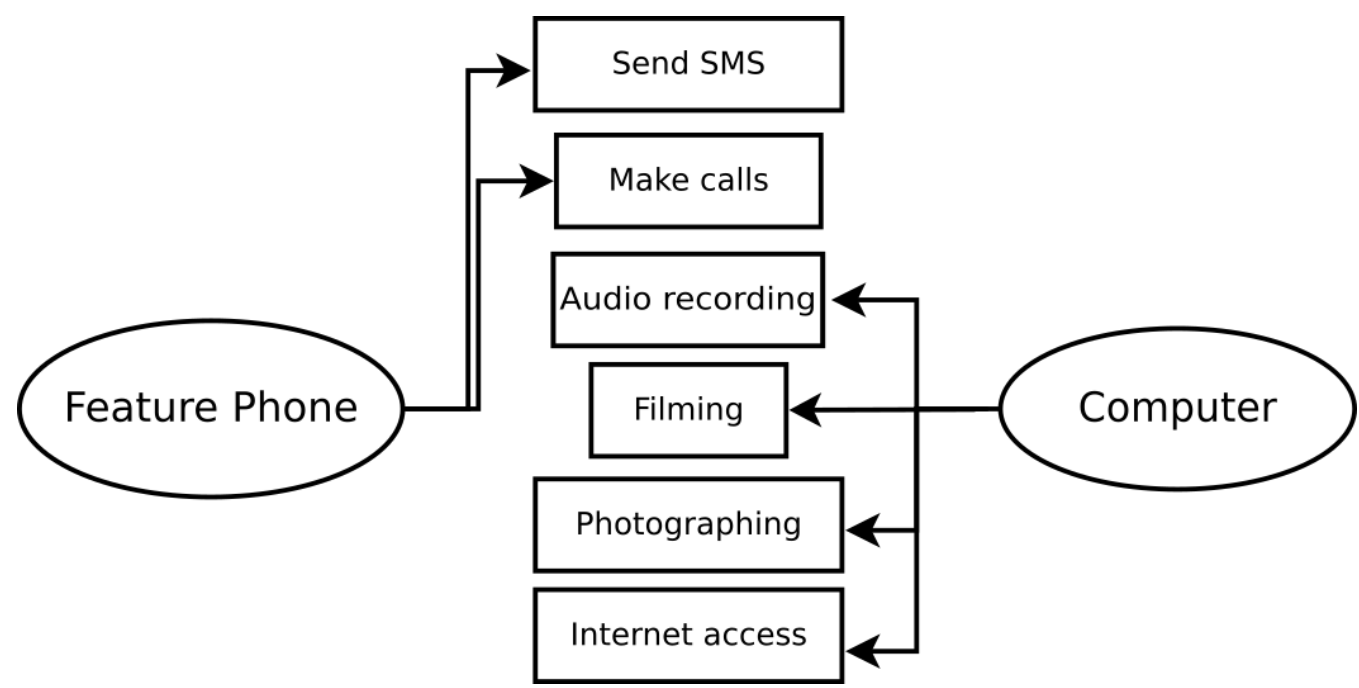

I remember how, in 1998, there was a degree of care with computers: plastic covers were used, people avoided touching the monitor screen with filthy fingers, and were afraid of breaking them. While this type of experience is still present, with many individuals expressing their desires to take courses to "learn to use the computer", experiences with smartphones have proved very different. No one mentions the need for a course to learn how to handle the devices, and the icons are almost self-explanatory: a figure of a camera activates the camera; a figure of the phone activates the dialler; and so forth. One can touch the screen all the time (that is what it was made for, after all), and it can be carried in one's pocket. In this sense, this nearness between individuals and materials promotes what Ingold (2012) defines as practical engagement, which results from the experience of individuals who construct their skills in specific environments. In the case at hand, the approximation of the Pataxó with these devices allows them to develop sensory perceptions which will lead to an improvement in practical skills and the refinement of knowledge.

These experiences are represented in a range of nuances, such as preferences for particular smartphone makers (maker A has a better camera, maker B is cheaper, maker $C$ has fewer problems, etc.), the age of users (elderly people still prefer feature phones, used only for phone calls), and differences in purchasing powers, given the greater costs in comparison to a regular phone. The phone also affords easier acquisition of the main apps. 
All that is needed is an internet connection and access to an "app store" to download WhatsApp and Facebook - when apps do not come preinstalled, as is the case with YouTube ${ }^{11}$. This is altogether a difference experience from that of finding someone who has an office suite, which, in order to download even a test version, one must have the requisite computer space.

Indeed, the most common app in Aldeia Velha is WhatsApp. The acquisition of smartphones is most often guided by its adaptability to this app: it must be able to install it, and new devices are desired because of their greater memory, the old phone being overburdened with the media generated and transacted by WhatsApp. It is interesting to observe that this union of smartphone and messenger app becomes a powerful tool for amplifying the performances and desires of people, with diverse techniques capable of being concatenated in varied operational sequences. While the computer is seen to be for the few, the smartphone, in a way, breaks through structures of power. While until recently an audio-visual project required borrowing a digital camera from someone, and to have a computer into which the file could be transferred, as well as an internet connection to upload it, now all that is needed is a smartphone, which can carry out all of these tasks.

Along with a camera and a computer, it is also necessary to connect to a video platform in order for the video to be shared. In figure 2 we can see how the smartphone is more intuitive, and has greater portability. If we take YouTube as an example, a user must have an account and to know how to upload videos. With the smartphone, the operational sequence (resources + skill) is more direct: of the exhibition of the video is to be restricted to the village, all that the user needs to do is to forward it with functions embedded in the app.

Figure 2: Resources needed to record and exhibit audio-visual content

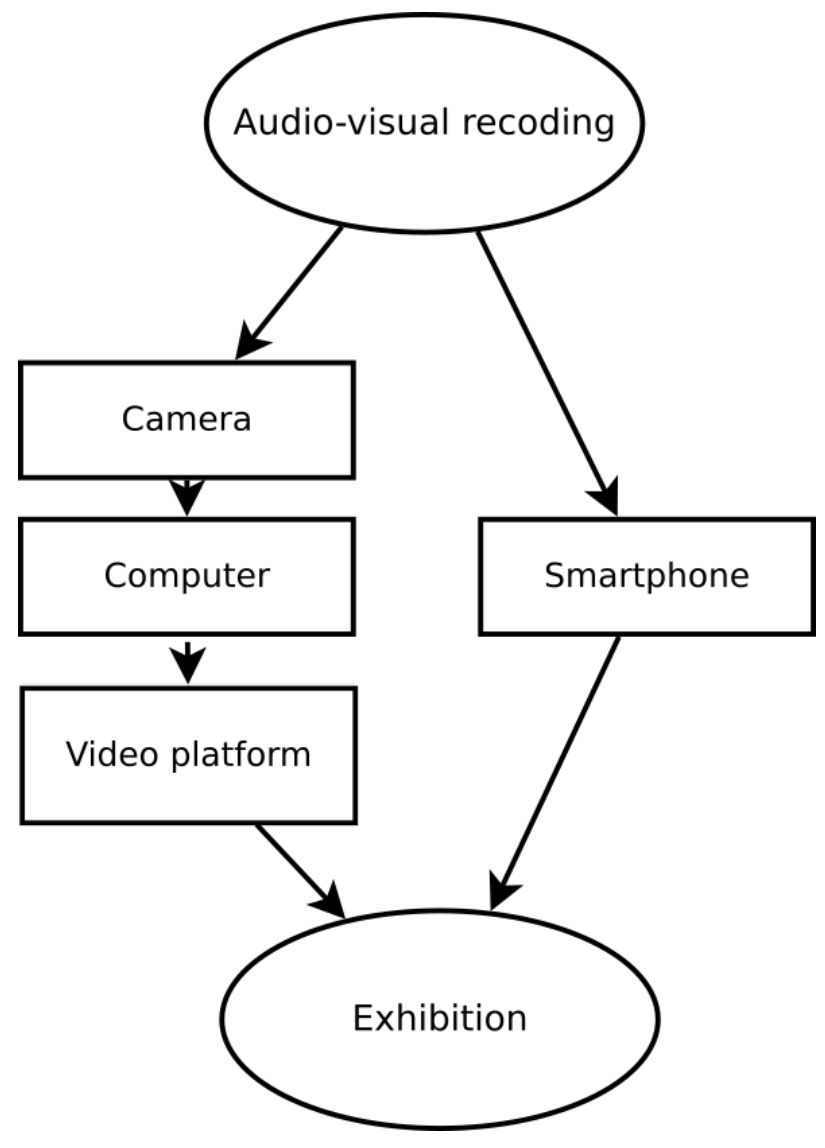

11 I mention WhatsApp, Facebook and YouTube because these are the most popular apps in Aldeia Velha. For more information, see: Ferreira Filho, 2017a; Ferreira Filho, 2017b . 
Services for recording and sharing videos are significantly different. Unlike YouTube, Instagram was designed to be used on the smartphone, providing filters and image editing possibilities without the use of the computer. In fact, users lose some of these exclusive resources when accessing Instagram outside of the app (in an internet browser, for instance). A more detailed analysis would consider different types of audio-visual work. Pataxó who have had some audio-visual training insist on using a camera and editing the file on the computer when preparing more elaborate videos. In terms of editing, we can find use of different software, from a basic Windows Movie Maker to the Cinelerra ${ }^{12}$ free software, or even some seen on a MacBook belonging to a visitor to Aldeia Velha.

This vocation for audio-visual productions is an important point for the present analysis, since it greatly facilitates communication between individuals in the village. A photo of something that one wants to share can be quickly taken, and it is possible to communicate through audio recordings, thereby avoiding the difficulties that are encountered when large fingers type on small keyboards. It also helps in terms of schoolwork, overcoming an inability to read and write, since all that is needed is to memorize certain icons and understand how the app works to send an audio recording: just open the app, choose the person who will receive the recording, hold down the microphone icon while recording, and that is it. If there is an internet connection, it will be sent.

As we can see here, social media is also a relevant technical factor when acquiring a smartphone, since, in conjunction with the many resources offered by a camera or a microphone, for example, they offer a more complete and economical type of communication. The completeness of this type of communication stems from the fact that users do not have to be alphabetized, since images and audio recordings can be used. Thus a message can be transmitted more directly between sender and receiver.

Many of the Pataxó have relatives that live in other villages. The configuration results in an intense flow between territories, making efficient and economical communication necessary. I have thus far mentioned some of the apps used for this communication, now I will provide the reason for certain choices.

Although Facebook was popular before WhatsApp, use of the latter is more widespread. A number of external matters may have led to this situation. For example, the fact that Facebook comes from a model which uses the browser, while WhatsApp was made for the smartphone. In this analysis, however, what matters are the local factors emerging from fieldwork. Here, there are a multiplicity of cases in which an individual can have accounts in both services or only in one. As I have mentioned, there is a preference for WhatsApp. If the smartphone has afforded a more intimate experience, the messaging service has proven to be more conducive to this usage.

Unlike Facebook, the central point of which is its timeline model, communicating via WhatsApp is more direct, and involves a more exact selection of who gets forwarded any message. Furthermore, it does not require that a further messaging service be installed, such as Facebook which requires users to install Facebook Messenger. It is also easier to manage messages through WhatsApp.

WhatsApp groups are a significant mirror of how social groups are organized. Families, school friends, teachers, village leaders, cultural groups, and so forth, all have their WhatsApp groups, in which both membership and content is managed. They are important channels of communication, from a simple "good morning" to gossip. It is also used for political mobilization, both by leaders of a single village and for intervillage movements. According to the inhabitants of the village, Facebook provides a different experience for its users. Whether it is the model for managing these groups, where it appears more complicated, or in its target audience, which for the Pataxó is more external than internal. The external audience here refers to people beyond daily contacts, with whom interaction is possible without having to supply your phone number.

12 Aldeia Velha actually had a specialist in Cinelerra, a non-linear editing system which is considered easy to learn, according to free software enthusiasts. 
Facebook also calls for greater care, because the timeline, the photo albums and the profile images are more public. In this way, the technical choice (LEMONNIER, 2006) varies according to strategies of (internal or external) efficacy, implying, to borrow Leroi-Gourhan's (1984) concept, a multilinear, rather than unilinear, technical tendency.

\section{Final Thoughts}

By questioning the use of computers in an Indigenous Land, we have interesting data that transcend the exoticization of certain usages which reactivate old dichotomies. By widening our view to include the amplitude of material relations, we can observe various nuances that, separated into exclusive factors - such as the technical, political, economic - tend to lose their complexity and therefore obscure important interactions between the actors.

The cases presented here can help us to make important connections with the matter of technique, which, rather than being isolated, deterministic or utilitarian, emerges as more general and attentive to levels of perceptions, skills, choices, systems and operational sequences. In what concerns the adoption and use of free software, for example, it is perfectly understandable that whoever adopts such an artefact does not necessarily adopt the meaningful set it is associated with. Resignifications occur as this set moves into a different environment. According to the needs of Aldeia Velha, the freedom of the software did not matter as much as its ease of use, both for neighbours (who could be called on to provide technical support) and externally. If there had previously been a certain hegemony of the Windows operating system, at present Android, the operating system of most smartphones, is based on GNU/Linux.

Despite the widespread use of smartphones, computers and the internet remain coveted resources. Computers still have their role to play, in the hierarchy and in specialization, and internet still provides a more efficient means of communication. Both are still very much restricted in Aldeia Velha, and out of need new strategies arise, mobilizing the actors involved in using this technology. There is a telling case, in which a student at the school, who introduces himself as a "hacker", narrated his techniques for obtaining access to the school's limited internet services. He says that, at the end of a class in which the laptop computer and the video projector were used, he helped the teacher tidy up. What he really wanted to do was to turn off the laptop, so that he could access and memorize the wi-fi password, which was only known to school employees. Knowing the password, he could spend time after school near the walls of the school, using its internet connection.

Wi-fi connection points transform social morphology, creating new spaces of sociability where teenagers and adults meet to talk, listen to music, and watch videos. These actions display great variability, particularly when we consider that mobility through the territory depends on the type of technical instrument utilized. Use of smartphones makes communication much faster, and this can have implications on political decisionmaking processes. There is thus a relation between the use of smartphones and the mobilization of people. It is impressive how much information gets disseminated without people actually needing to move around. Such a dynamic transforms social morphology in what concerns the spatial mobility of subjects, as well as the social organization of this information and of the technical instruments used in this communicative process.

Wi-fi hotspots are also areas in which people go to communicate with those who are close by to show a video to someone, for example. Regarding these transformations, I think we can list important parameters which should be taken into consideration.

First, however, I will narrate an exemplary case. The culture point was going to get internet access through a donation from a small local provider, and was deciding on how to divide up the resources. The administrator of the point felt that access should be public, but with one small caveat. Whenever the space needed a fast connection, it would bar other people from accessing its internet. 
Along with issues of mobility, a wi-fi hotspot also reveals other nuances. If we consider that the plan to block internet access was successful, we see that those who were outside the culture point only have variable internet access. Faced with this instability, certain actions can be taken which depend on the relationship between an individual and the space. Kinship, political positions, religion - all can affect how an individual can access the internet. It is thus evident that modifications in social morphology through the incorporation of new techniques do not occur through substitution, but by a gradation of forms of political organization where communication is vital within the dynamics of territory.

New forms of communication also contribute to this transformation. There has been an increase in storage capacity, through electronic memory chips, for example, and also a greater diffusion of knowledge. There is thus a movement not only of people, but also of objects and techniques. It is likewise noticeable that relations of power and social organization are reflected in social network and messenger service groupings. News of kinspeople that had formerly taken a long time to cross the village are at present organized by WhatsApp groups.

The chief communicates through an audio recording, news that is of interest to everyone. Leaders of neighbouring villages negotiate the times and places of the next meetings. Groups organize support for this or that leader. Teachers discuss the controversial acts of the Secretary of Education.

Finally, I hope I have made it clear that it is important to analyse information and communication technology through the frameworks of the anthropology of technique. With the data I have presented here, I would say that the technical tendencies identified are not generalizable, but refer, instead, to a local dimension. In other contexts, such as, for example, in the academy and in certain professional spheres, smartphones do not substitute for the computer, and the smartphone, the tablet, and so forth, each has its appropriate activity. Yet when there is no specialized use, and/or when income is low, as with the Pataxó, we can apprehend intentionalities that lead us to substitute or privilege one device over others. For the Pataxó, where communicating via audios and images is more common, the smartphone - and a messenger app like WhatsApp - ensures greater mobility than a computer (even a laptop computer) and ensures the greater efficiency of the type of communication they prefer: fast, direct, not dependent on writing. The speed with which news is disseminated, new gadgets are released or new resources become available in the most popular apps, requires that we remain attentive to new tendencies, re-elaborations, concatenations, that can be transformed through these relations.

Received: September 19, 2018

Approved: October 30, 2019

Translated by Luiz Costa 


\section{References}

AKRICH, Madeleine. 1992. "The de-scription of technical objects. Shaping Technology|Building Society". Studies in Sociotechnical Change, MIT Press, pp. 205-224.

ATROCH, Nathalia da Matta. 2015. O Desmantelamento do Conceito de Inclusão Digital: uma sociologia das associações da rede metareciclagem. Dissertação de Mestrado, Universidade Federal de Pernambuco - Recife.

BARTH, Fredrik. 200o. O guru, o iniciador e outras variações antropológicas. Rio de Janeiro: Contra Capa.

IBGE. "PNAD TIC: em 2014, pela primeira vez, celulares superaram microcomputadores no acesso domiciliar à Internet”. Última Atualização Maio 25, 2017. https:|/agenciadenoticias.ibge.gov.br/agenciasala-de-imprensa/2013-agencia-de-noticias/releases/9564-pnad-tic-em-2014-pela-primeira-vez-celularessuperaram-microcomputadores-no-acesso-domiciliar-a-internet.html

FUNAI. “Terras indígenas”. Ministério da Justiça, Maio 20, 2018. http:||www.funai.gov.br/terra_indigena_3/ mapa/index.php?cod_ti=gor

CARVALHO, Maria Rosário Gonçalves de. 1977. Os Pataxó de Barra Velha: Seu subsistema econômico. Dissertação de Mestrado, Universidade Federal da Bahia - Salvador.

CRESSWELL, Robert. 1983. "Transferts de techniques et chaines operatoires". Techniques \& Culture. 2: 143-163. . 1994. "La nature cyclique des relations entre le technique et le social. approche technologique de la chaîne opératoire”. In: B. Latour (org), De la prêhistoire aux missiles balistiques. Paris: La Découverte. pp. 273-289.

FERREIRA FILHO, Isaac Fernando. 2017a. O Indígena Frente as Políticas de Inclusão Digital: Uma Análise de Processos Sociotécnicos entre os Pataxó da Aldeia Velha no Extremo Sul da Bahia. Dissertação de Mestrado, Universidade Federal da Paraíba - João Pessoa.

, Isaac Fernando. 2017b. "Entre expectativas e práticas: uma análise das atividades de inclusão digital na Aldeia Velha - BA”. In: A. Barbosa da Silva, B. Sousa, F. Mura e R. Henrique (org.). Território, ambiente, identidade e poder: reflexões a partir de múltiplas perspectivas. João Pessoa: Editora da UFPB. pp. 237-254.

GRÜNEWALD, Rodrigo de Azeredo. 2002. "Os pataxó e os fluxos coloniais." Encontro Anual da ANPOCS. http://www.anpocs.com/index.php/encontros/papers/26-encontro-anual-da-anpocs/gt-23/gt15-19/4457rgrunewald-os-pataxo/file.

INGOLD, Tim. 1988. "Tools, minds and machines: an excursion in the philosophy of technology". Techniques et Culture, 13: 151-176.

, Tim.; KURTTILA, Terhi. 2000. "Perceiving the environment in finnish lapland”. Body and Society, 6(4): $183-196$.

, Tim. 2012. "Trazendo as coisas de volta à vida: emaranhados criativos num mundo de materiais". Horizontes Antropológicos, 18(37): 25-44.

LEMONNIER, Pierre. 2006. "Introduction”. In: P. Lemonnier (org.). Technological choices: transformation in material cultures since the Neolithic. London: Routledge. pp. 1-35.

LÉVY, Pierre. 1993. As Tecnologias da Inteligência: O futuro do pensamento na era da informática. São Paulo: Editora 34 .

LEROI-GOURHAN, André. 1984. Evolução e Técnicas I: O homem e a matéria. Lisboa: Edições 70. , André. 1987. O Gesto e a Palavra II: Memória e ritmo. Lisboa: Edições 70.

MAUSS, Marcel. 2015a. "As técnicas do corpo". In: M. Mauss (org). Sociologia e Antropologia. São Paulo: Cosac Naify. pp. 398-420.

, Marcel. 2015b. “Ensaio sobre as variações sazonais das sociedades esquimós”. In: M. Mauss (org).

Sociologia e Antropologia. São Paulo: Cosac Naify. pp. 423-501. 
MILLER, Daniel.; HORST, Heather. 2015. “O Digital e o Humano: prospecto para uma Antropologia Digital”. Parágrafo, 3(2): pp. 91-112.

, Daniel. et al. 2016. How the world changed social media. London: UCL press.

MURA. Fabio. 200o. Habitações Kaiowa: formas, propriedades técnicas e organização social. Dissertação de Mestrado, Museu Nacional - Universidade Federal do Rio de Janeiro - Rio de Janeiro. . Fabio. 2006. À Procura do "Bom Viver": Território, tradição de conhecimento e ecologia doméstica entre os Kaiowa. Tese de Doutorado, Museu Nacional - Universidade Federal do Rio de Janeiro - Rio de Janeiro. , Fabio. 2011. "De sujeitos e objetos: um ensaio crítico de antropologia da técnica e da tecnologia". Horizontes Antropológicos, Porto Alegre, 17(36): pp. 95-125. Fabio. 2017. "A política como técnica de uso e como ato transformador: algumas reflexões a partir do caso dos Kaiowa de Mato Grosso do Sul”. In: C. Sautchuk (org). Técnica e transformação: perspectivas antropológicas. Rio de Janeiro: ABA Publicações. pp. 37-66.

MURILLO, Luis Felipe Rosado. 2009. Tecnologia, Política e Cultura na Comunidade Brasileira de Software Livre e de Código Aberto. Dissertação de Mestrado, Universidade Federal do Rio Grande do Sul - Porto Alegre.

OLIVEIRA, João Pacheco de. 1998. "Uma etnologia dos" índios misturados”? Situação colonial, territorialização e fluxos culturais”. Mana, 4(1): pp. 47-77.

PFAFFENBERGER, Bryan. 1992. "Social anthropology of technology. Annual review of anthropology", Virginia, 21(1): pp. 491-516.

RIBEIRO, Gustavo Lins. 2008. "Poder, redes e ideologia no campo do desenvolvimento". Novos estudosCEBRAP, 80: pp. 109-125.

ROSSI, Paolo. 1989. Os Filósofos e as Máquinas. São Paulo: Editora Schwarcz.

SAUTCHUK, Carlos Emanuel. 2010. "Ciência e técnica”. In: C. Martins (org), Horizontes das ciências sociais no Brasil, São Paulo: ANPOCS. pp. 97-122.

SIGAUT, François. “Technology”. 1994. In: T. Ingold (org.), Companion encyclopedia of anthropology: humanity, culture and social life. London: Routledge. pp. 420-459.

SIMONDON, Gilbert. 2007. El modo de existencia de los objetos técnicos. Buenos Aires:

Prometeo Libros Editorial.

UCL Anthropology. Disponível em: https://blogs.ucl.ac.uk/assa/. Acesso em: Mai. 2018.

UNIVERSIDADE DO PARÁ. “História da informática e da internet”. Última Atualização Abril 20, 2015. http://www.ufpa.br/dicas/net1/int-hind.htm.

\section{Isaac Fernando Ferreira Filho}

Researcher at the Technical Process Studies Laboratory, Federal University of Paraíba. https://orcid.org/0000-0001-6708-0090

Author's email: isaacmob@gmail.com 